Journal of Physical Science, Vol. 29(Supp. 2), 77-98, 2018

\title{
Behaviour of Over-reinforced Concrete Beams with Double Helix and Double Square Confinements Related to Ultimate Bending and Shear Strength
}

\author{
Horng Hean Tee, ${ }^{*}$ Kousay Al-Sanjery and Jeffrey Choong Luin Chiang \\ Faculty of Engineering and Built Environment, SEGi University, \\ 9 Jalan Teknologi, Taman Sains Selangor, PJU 5, Kota Damansara, \\ 47810 Petaling Jaya, Selangor, Malaysia \\ *Corresponding author: teehornghean@segi.edu.my
}

Published online: 30 July 2018

To cite this article: Horng, H. T., Al-Sanjery, K. \& Choong, J. L. C. (2018). Behaviour of over-reinforced concrete beams with double helix and double square confinements related to ultimate bending and shear strength. J. Phys. Sci., 29(Supp. 2), 77-98, https:// doi.org/10.21315/jps2018.29.s2.7

To link to this article: https://doi.org/10.21315/jps2018.29.s2.7

\begin{abstract}
Over-reinforced concrete beams with compression zones confined with double helix and double square shaped steel confinement reinforcements were studied with respect to flexural strength, shear strength and deflection. Seven reinforced concrete $(R C)$ beams, $200 \mathrm{~mm}$ (width) $\times 300 \mathrm{~mm}$ (depth) $\times 3000 \mathrm{~mm}$ (length) with four incorporating $1.42 \rho_{b}$ and the remaining $1.64 \rho_{b}$ (where $\rho b$ is the balanced steel ratio) were tested under four-point static load tests. The confinements consisted of $6 \mathrm{~mm}$ diameter reinforcements with nominal yield stress of $275 \mathrm{~N} \mathrm{~mm}^{-2}$ and pitches of $50 \mathrm{~mm}$. A previous investigation by the authors indicated that to utilise fully the ultimate bending strength of concrete beams with confinements in the compression zones, the shear strength of such beams should be enhanced by adopting the diagonal compressive strut angle $(\theta)$ of more than $22^{\circ}$ recommended in Eurocode 2 (EC2). It was found that the failure loads are higher than the control beams' calculated ultimate loads. Deflections of beams with confinement were less compared to the beams without confinements. Control beams failed in shear because of no shear strength enhancement whereas all confined beams failed in flexural/ compression mode and gave fair warning against failure. The cracking behaviour was the same for all beams with vertical tensile cracks at the constant moment zone and inclined cracks at the shear span. After failure, it was found that the concrete core confined was still intact. To check on the concrete compressive strength, eight concrete cylinders of diameter $100 \mathrm{~mm}$ were prepared, six of them were confined with helical reinforcements with $50 \mathrm{~mm}$ pitch, and two without confinements. It was found that with confinements, the cylindrical
\end{abstract}

(C) Penerbit Universiti Sains Malaysia, 2018. This work is licensed under the terms of the Creative Commons Attribution (CC BY) (http://creativecommons.org/licenses/by/4.0/). 
compressive strength increased between 1.34 and 2.22 times that of unconfined concrete cylinder strength.

Keywords: Double helix, reinforced concrete, over reinforced beams, deflection, confined concrete

\section{INTRODUCTION}

It is a well-known fact that links in compression members prevent buckling of longitudinal reinforcements and also act as a confinement to concrete, enhancing its ductility. The use of confinements minimises the Poisson's ratio effect, i.e., less lateral strain would occur compared with the condition where there are no confinements in particularly high levels of stress. The use of continuous helical links in elements such as columns can tremendously reduce the fabrication time.

Confinement of concrete in reinforced concrete flexural members would have the same effect in reducing the developed strain values, enhancing the concrete ductility and resulting in higher absorbing energy of the concrete. This allows beams with confined concrete in the compression zone to sustain higher ultimate load. In addition, the beam will have a better warning against failure, especially for beam reinforced with a percentage of steel higher than the balanced steel ratio stipulated by most of current codes of practice. Therefore, with confinement, steel ratio higher than the balance can be used which can also be cost effective. With this regard, more techniques for concrete confinement need to be provided and more research is required to investigate other critical and practical aspects of shear and flexural failures in reinforced confined concrete beams.

As early as mid-1890s, experimentation has been done on concrete reinforcements adopting helical reinforcements which recognised that helical reinforcements offer better resistance compared to concrete adopting longitudinal bars with lateral ties. ${ }^{1}$ It is well established that there will be increase in compression strength for confined concrete because hooping prevents the swelling of the concrete and thereby the ability to resist higher pressures. ${ }^{2}$ The equation for the stress-strain relationship for plain concrete in compression in the form of serpentine was presented by Carreira and Chu and later, stress-strain relationship for compression for confined concrete was studied by Mander et al.,4

Some researchers had carried out compression tests on $150 \mathrm{~mm} \times 150 \mathrm{~mm} \times$ $750 \mathrm{~mm}$ by varying the stirrup spacing but found that the compressive strength was unaffected. Their experiments were conducted on concrete column samples 
with non-continuous ties with spacing of $125 \mathrm{~mm}, 187 \mathrm{~mm}$ and $375 \mathrm{~mm}$ intended to determine the effects of link spacing and steel fibre volume on the ductility and compressive strength of concrete. It was revealed that the compressive strength was unaffected by both variables but ductility improved with lesser link spacing and higher steel fibre volume. ${ }^{5}$

In another experiment, samples of $150 \mathrm{~mm} \times 150 \mathrm{~mm} \times 1150 \mathrm{~mm}$ high strength and normal grade concrete were carried out and by varying stirrup spacing by $50 \mathrm{~mm}, 100 \mathrm{~mm}$ and $150 \mathrm{~mm}$. The intention of this research was to determine the effects of small eccentricity in columns and the result was that high strength concrete (HSC) specimens with $50 \mathrm{~mm}$ stirrup spacing was able to achieve $4.5 \%$ more in terms of ultimate force compared with that of the sample with a spacing of $150 \mathrm{~mm}$. On the other hand, for the normal grade concrete, samples with stirrup spacing of $50 \mathrm{~mm}$ was able to achieve $2.5 \%$ higher ultimate load compared to the sample with $150 \mathrm{~mm}$ stirrup spacing. ${ }^{6}$

Marvel et al. investigated the behaviour of high strength reinforced concrete columns confined with double helix. ${ }^{7}$ It was concluded that columns confined with double helix with the same volumetric confining ratios as the single helix had a similar ultimate strength, increased ultimate strain and increased ductility. ${ }^{7}$ It should be noted that these studies were carried out on columns which are members in direct compression.

Further research works have also been carried out on flexural concrete members with confined concrete. Most of current codes of practice for reinforced concrete members recommend under-reinforced or balanced design criteria for design. This is basically to avoid brittle failure behaviour. However, some previous research works indicated that over-reinforced concrete beams could be used with proper confinement of concrete in the compression zone..$^{8-10}$ Though over-reinforced beams with no confinements in the compression zone will result in catastrophic compression failure, studies carried out on confined reinforced concrete beams generally indicated an increase in ductility. ${ }^{11-15}$

\section{LITERATURE REVIEW}

The effects of two different confinement shapes, i.e., one single helical confinement and a twin pair of side-by-side helical confinement for five over-reinforced HSC beams of $200 \mathrm{~mm}$ (width) $\times 300 \mathrm{~mm}($ depth $) \times 3700 \mathrm{~mm}$ (clear span) were studied by Jeffry and Hadi. ${ }^{16}$ The aim of their experiment was to study the ductility behaviour. It was concluded that during the elastic stage, the mid-span deflection 
for both single and double helix were similar. But the confinement effects start off earlier with the twin helices. Beams with single confinement was more ductile compared to beams with twin confinement. ${ }^{16}$

Kuttab and Haldane carried out an experiment on 5 beams with dimensions $100 \mathrm{~mm}$ (width) $\times 110 \mathrm{~mm}$ (effective depth) $\times 1500 \mathrm{~mm}$ (clear span) in order to investigate whether confining the concrete at the compression zone could increase the shear capacity of the beam. The experiment had three specimens of beams where at the constant moment zone, the shear links' legs did not extend below the neutral axis. It was discovered that concrete beam samples with shear link legs that did not extend below the neutral axis possess $7 \%$ and $20 \%$ higher shear capacity and ductility respectively compared to the sample with shear link legs extending below the neutral axis. This is owing to the confinement which limits the lateral strain of the compressive zone resulting in a multiaxial state of stress in the compressive zone. ${ }^{17}$

Experiments were carried out by Elbasha and Hadi to study the effects of helical pitch and tensile reinforcement ratio on the concrete cover spalling off load and ductility in HSC beams. ${ }^{18}$ Eight $200 \mathrm{~mm} \times 300 \mathrm{~mm} \times 4000 \mathrm{~mm}$ beams with varying helical pitches and longitudinal reinforcement ratios were experimented to study the effects on concrete cover spalling off and displacement ductility. It was concluded that the spalling off load increased linearly and the ultimate load decreased as the helical pitch increased. The displacement ductility increased with the decrease in helical pitch..$^{18,19}$

Elbasha and Hadi also conducted a research on five full-scale beams of $200 \mathrm{~mm} \times 300 \mathrm{~mm} \times 4000 \mathrm{~mm}$ with helical confinement in the compression zone by varying the tensile reinforcement ratios and concrete compressive strengths to study the behaviour of over-reinforced concrete beams. The study concluded that for over-reinforced HSC beams with helical confinement, increasing the concrete compressive strength reduced both yields and ultimate deflections at failure. The displacement ductility index decreases with the increase in concrete compressive strength. The effects of increasing longitudinal reinforcement ratio resulted in beams being able to experience higher ultimate deflection and increased the displacement ductility index..$^{20}$

More recently, a study on the effects of confinements in the form of links and longitudinal rebars in the compression zone was carried out on two sets of $\mathrm{RC}$ beams where the first set was of dimensions $175 \mathrm{~mm}$ (width) $\times 300 \mathrm{~mm}$ (depth) $\times 2400 \mathrm{~mm}$ (length) while the other was of $150 \mathrm{~mm}$ (width) $\times 300 \mathrm{~mm}$ (depth) $\times$ $2400 \mathrm{~mm}$ (length). ${ }^{13}$ The confinements used were of $8 \mathrm{~mm}$ diameter with $50 \mathrm{~mm}$ and 
$100 \mathrm{~mm}$ pitches. The control beams did not have any confinement reinforcements. It was concluded that additional confinement result in an increased up to $300 \%$ in concrete strain compared to those without confinements. ${ }^{13}$

Previous research works on beams with concrete confinements adopted either single helix or continuous square. There were hardly any study carried out on beams with double helix. Previous work by the authors indicated that the shear strength of over-reinforced concrete beams designed as per EC2 should be adopting the diagonal compressive strut angle, $\theta$ of more than $22^{\circ} .{ }^{21}$ The use of double helix in this research took into account of adopting the diagonal compressive strut angle, $\theta$ of more than $22^{\circ}$. It was essential that this research extended to the most efficient shape of steel to confine the concrete, which result in improving behaviour of over reinforced concrete beams.

\section{EXPERIMENTAL}

\subsection{Beam Specimens and Cylinders}

Seven full-scaled RC beams of $200 \mathrm{~mm} \times 300 \mathrm{~mm} \times 3000 \mathrm{~mm}$ simply supported with a span of $2700 \mathrm{~mm}$ were prepared and tested under four-point static load tests (Figure 1). Table 1 tabulates the details of the beams, where two longitudinal tensile steel reinforcement ratios $(\rho)$ were used namely $3.41 \%$ and $3.92 \%$. These correspond to $1.42 \rho_{\mathrm{b}}$ and $1.64 \rho_{\mathrm{b}}$ where $\rho_{\mathrm{b}}$ is the balanced steel ratio. Two control beams B1 C142 and B5 C164 with no confinements were tested. The coding of the beams as shown in Table 1 consists of three sets of information. B1, B2, etc., indicates the beam number. For the second set of coding, $\mathrm{C}$ represents the control beam, DH represents double helix in opposing direction configuration, DSQ represents double square and DHSH represents double helix in the same direction configuration. The final set of coding is related to the balanced steel ratio, $\rho_{\mathrm{b}}$.

The double helix confinement is constructed from two helixes, one in the clockwise and the other counter-clockwise direction. The shapes of these confinements are as shown in Figure 3. For all confined concrete beams, the beams incorporating $6 \mathrm{~mm}$ diameter with $50 \mathrm{~mm}$ pitch confinements in the compression zones were reinforced with H10-50 mm shear links at the shear span only (Figure 1). The control beams were reinforced with shear links of $\mathrm{H} 8-125 \mathrm{~mm}$ at the shear span. 
Table 1: Details of beams.

\begin{tabular}{llllll}
\hline Sample & $\begin{array}{l}\text { Longitudinal } \\
\text { reinforcement } \\
\text { ratio } \rho(\%)\end{array}$ & $\begin{array}{l}\text { Number and } \\
\text { diameter of } \\
\text { bars }\left(\mathrm{A}_{\text {st }}\right)\end{array}$ & $\begin{array}{l}\text { Longitudinal } \\
\text { reinforcement } \\
\text { ratio in terms } \\
\text { of }\left(\rho_{\mathrm{b}}\right)\end{array}$ & $\begin{array}{l}\text { Confinement } \\
\text { pitch at } \\
\text { constant } \\
\text { moment zone } \\
(\mathrm{mm})\end{array}$ & $\begin{array}{l}\text { Shear span } \\
\text { links }\end{array}$ \\
\hline B1 C 142 & 3.41 & $4 \mathrm{~T} 20+2 \mathrm{~T} 16$ & 1.42 & - & H8-125 \\
B2 DH 142 & 3.41 & $4 \mathrm{~T} 20+2 \mathrm{~T} 16$ & 1.42 & 50 & H10-50 \\
B3 DSQ 142 & 3.41 & $4 \mathrm{~T} 20+2 \mathrm{~T} 16$ & 1.42 & 50 & H10-50 \\
B4 DHSD 142 & 3.41 & $4 \mathrm{~T} 20+2 \mathrm{~T} 16$ & 1.42 & 50 & H10-50 \\
B5 C 164 & 3.92 & $6 \mathrm{~T} 20$ & 1.64 & - & H8-125 \\
B6 DH 164 & 3.92 & $6 \mathrm{~T} 20$ & 1.64 & 50 & H10-50 \\
B7 DSQ 164 & 3.92 & $6 \mathrm{~T} 20$ & 1.64 & 50 & H10-50 \\
\hline
\end{tabular}
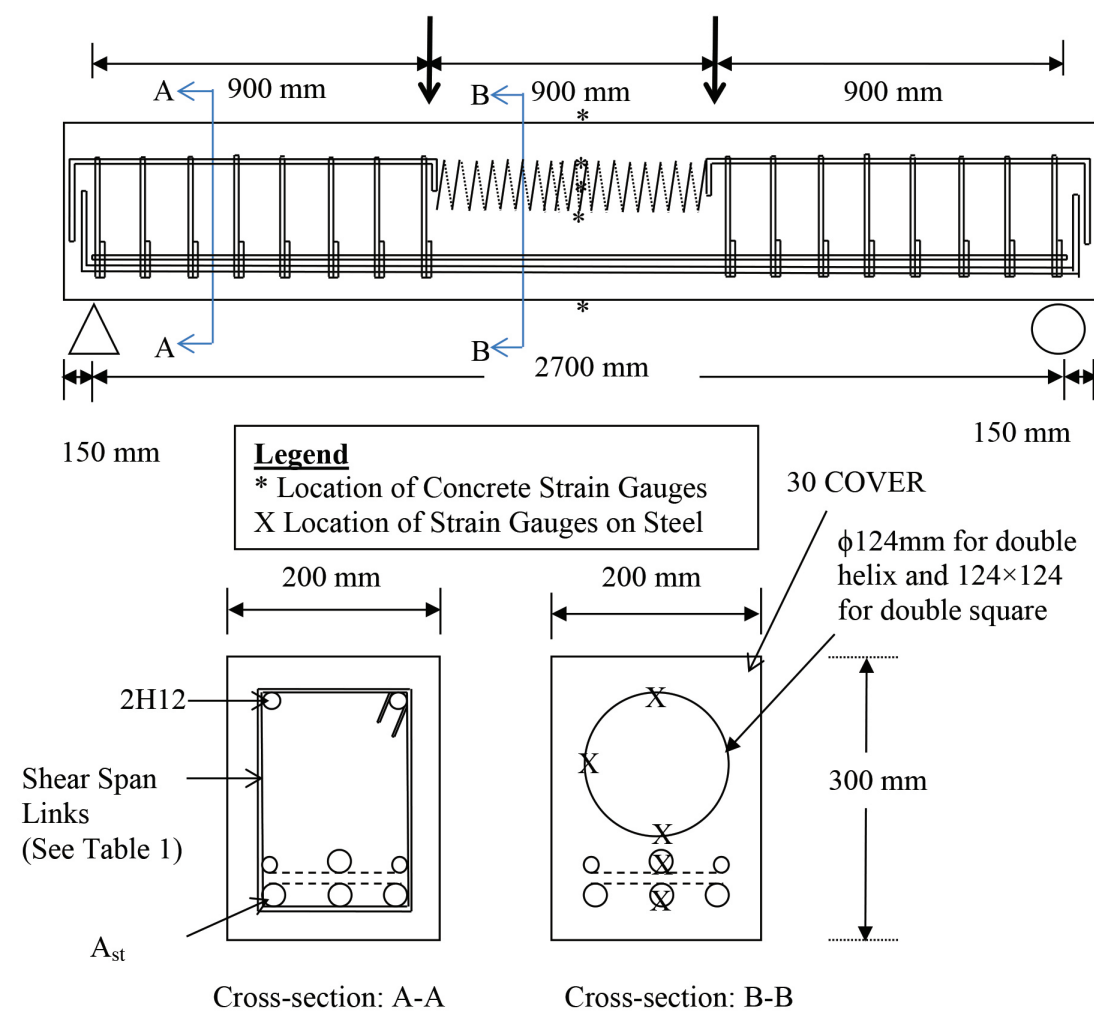

Figure 1: Loading arrangement and reinforcement details for beams with concrete confinements. 


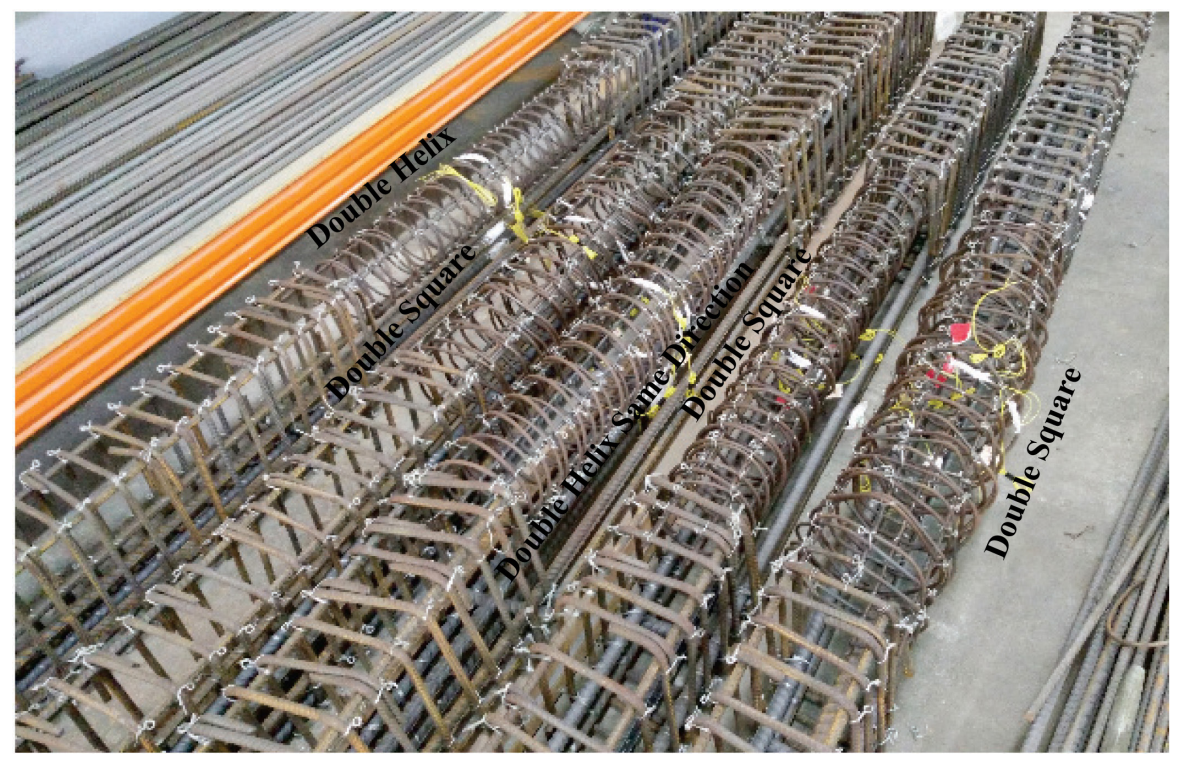

Figure 2: Beams with different confinement shapes.

Eight concrete cylinders were cast and tested for concrete compression cylinder strength. Two are plain concrete while the others are confined with steel confinement reinforcements with a pitch of $50 \mathrm{~mm}$ (Figure 3). Coarse aggregates of approximately $5 \mathrm{~mm}$ to $10 \mathrm{~mm}$ were used in the mix. The average compressive strengths of the samples are shown in Table 2.

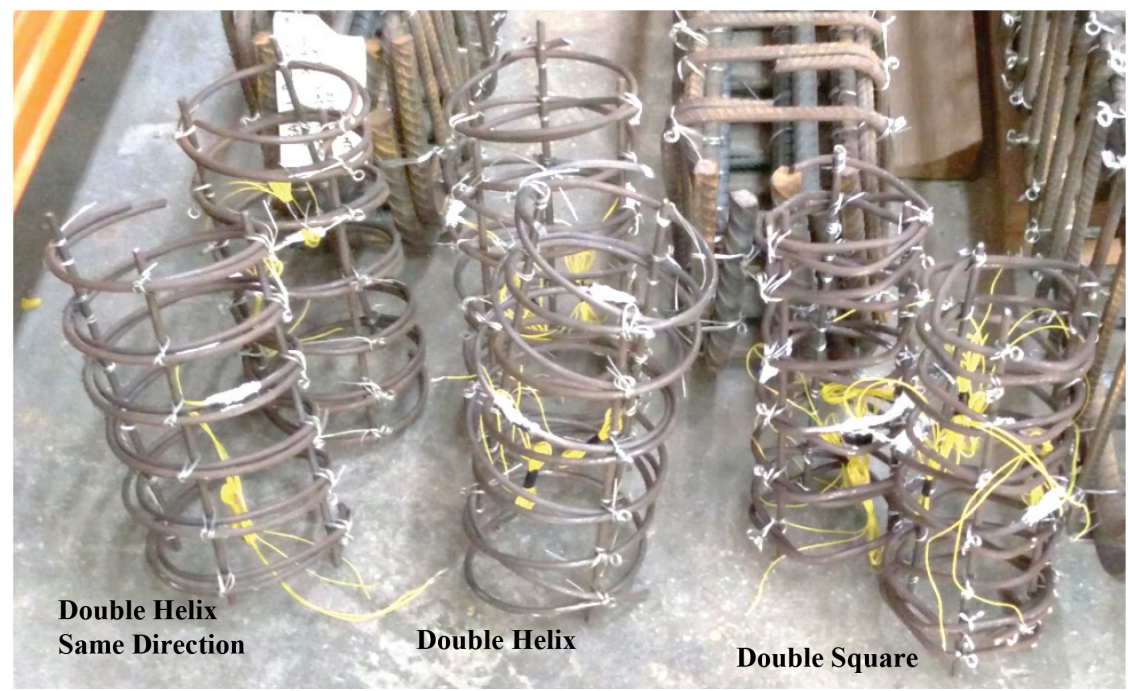

Figure 3: Confinement shapes. 
Table 2: Average cylindrical concrete compressive strength.

\begin{tabular}{ll}
\hline Specimens & Average compressive strength $\left(\mathrm{N} \mathrm{mm}^{-2}\right)$ \\
\hline Plain concrete & 63.1 (cylindrical) \\
Plain concrete & 58.1 (cylindrical) \\
Double square & 93.5 (cylindrical) \\
Double square & 85.1 (cylindrical) \\
Double helix same direction & 139.9 (cylindrical) \\
Double helix same direction & 123.3 (cylindrical) \\
Double helix & 127.1 (cylindrical) \\
Double helix & 123.7 (cylindrical) \\
\hline
\end{tabular}

For the reinforcements used, diameter $6 \mathrm{~mm}$ steel with nominal yield stress, $\mathrm{f}_{\mathrm{y}}=275 \mathrm{~N} \mathrm{~mm}^{-2}$ for confinements and diameter $10 \mathrm{~mm}$ steel with nominal yield stress of $460 \mathrm{~N} \mathrm{~mm}^{-2}$ for links were adopted. The tensile reinforcements with diameters of $16 \mathrm{~mm}$ and $20 \mathrm{~mm}$ with nominal yield stress, $\mathrm{f}_{\mathrm{y}}=460 \mathrm{~N} \mathrm{~mm}^{-2}$ were adopted as main reinforcement bars.

\subsection{Tests}

All the beams were tested under four-point static loading tests. Instron $600 \mathrm{kN}$ Automatic Compression Testing Machine (ACTM) was used and the loading applied was at a rate of $5 \mathrm{kN} \mathrm{min}^{-1}$. Strain measurements on the concrete across the total depth of the beams and directly on the tension steel were taken. These were measured using electrical strain gauges connected to a data logger. The deflection at the centre of the beam was measured with a linear variable displacement transducers (LVDT). The setup of the experiment is as shown in Figure 4. 


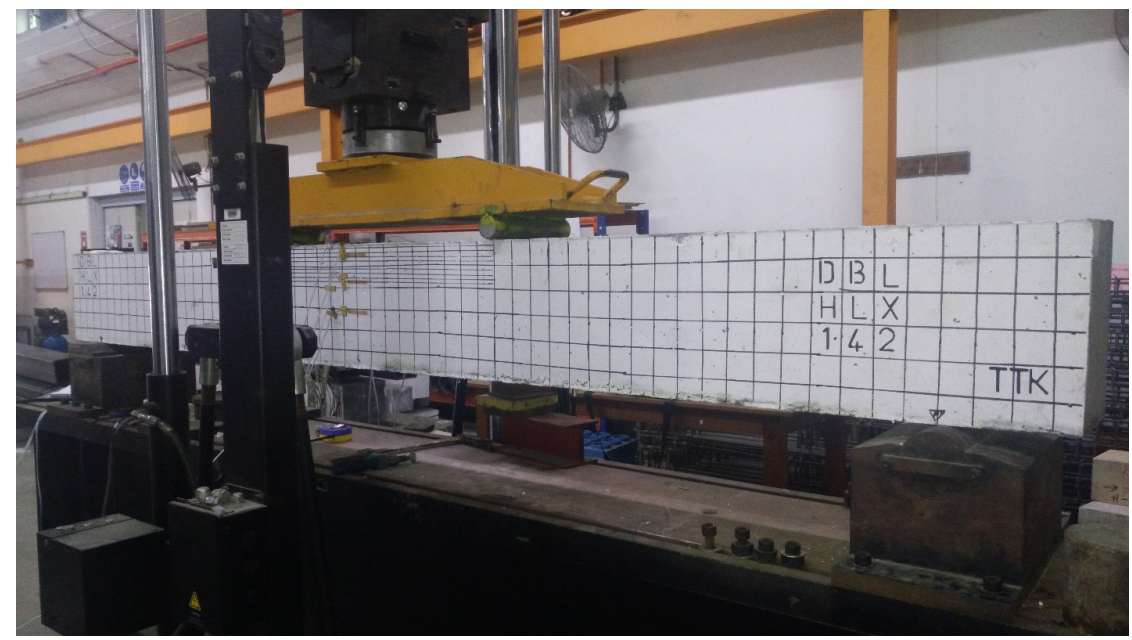

Figure 4: Experimental setup.

\section{RESULTS AND DISCUSSION}

\subsection{Strains Measurement and Neutral Axis Depth}

Higher level of neutral axis depths generally is recommended to ensure a behaviour similar to under-reinforced beams with respect to good warning against failure. Strain profiles for the beams approaching their failure loads are as shown in Figure 5. From the strain profiles, it was observed that the neutral axis depths of the beams for the $1.42 \rho_{\mathrm{b}}$ category was $0.45 \mathrm{~d}$ for double helix confinement, $0.62 \mathrm{~d}$ for double square confinement and $0.69 \mathrm{~d}$ for double helix, same direction confinement. Under $\mathrm{EC} 2$, it is recommended that the neutral axis depth of $0.35 \mathrm{~d}$ should not be exceeded for concrete grade $\mathrm{C} 40 / 50$ or higher. ${ }^{22}$

For beams with the $1.64 \rho_{\mathrm{b}}$ category, it was found that the neutral axis depths were $0.55 \mathrm{~d}$ for double helix confinements and $0.72 \mathrm{~d}$ for double square confinements. The control beams had a neutral axis depth of $0.48 \mathrm{~d}$. This indicates that with confinement, lower neutral axis depth is resulted due to lower values of compressive strain. This exposes larger area of concrete in compression. Furthermore, lower strain values of tension and compression indicate lower curvature and consequently lead to lower deflection values.

Although a lower neutral axis depth of more than $0.35 \mathrm{~d}$ limit recommended by the code was encountered, the beams did not fail catastrophically and gave good 
warning against failure. Furthermore, when the concrete cover spalled off first indicating initial failure, it was finally followed by compression failure.

It was noted that the compressive strain in the confined concrete follow the straight line theory of strain profile. At the same time, higher values of strain more than 0.0035 have been achieved. However, the strain at the unconfined concrete cover was less and also does not follow the straight line strain profile criteria. This clearly shows that confined concrete can be strained more than unconfined concrete (Figure 6).

The confinements adopted were of diameter $124 \mathrm{~mm}$ and $124 \mathrm{~mm}$ square. From Figure 5, it can be seen that the neutral axes for all the beams except for B2 and B6 (double helix confinements) are located almost at the boundary of confinements.

During the beam failure loads, for beams with the $1.42 \rho_{\mathrm{b}}$ category, the longitudinal tensile reinforcement strains were approximately similar for both beams B2 (double helix confinements) and B3 (double square confinements). The strain gauge for beam B2 (double helix confinement) located at the bottom most layer of tensile reinforcements malfunctioned and no readings were obtained. For beam B4 (double helix, same direction confinements), the strain at the bottom most layer of the tensile reinforcements was higher than beam B3 (double square confinements).

For beams with the $1.64 \rho_{\mathrm{b}}$ category, during the failure loads of the beams, the longitudinal tensile reinforcement strain for B6 (double helix) was less than B7 (double square).

Table 3 shows the tensile strain at the main rebar level and compressive strain at load approaching failure. Figure 5 shows the maximum compressive strain at the concrete compression zone for beams with $\rho=1.42 \rho_{\mathrm{b}}$ and $\rho=1.64 \rho_{\mathrm{b}}$. It can be seen that with the introduction of concrete confinement, the strains of both tension and compression of the specimens are less than the control beam due to the confinement effect, i.e., the helical confinements assisted in minimising the Poisson's effects.

At the same level of stress and nearing the failure loads of the beams with confinements (B2, B3 and B4) and of the category $\rho=1.42 \rho_{b}$, a maximum concrete compressive strain of a similar value was observed, i.e., approximately $2700 \times 10^{-6}$ as shown in Figure 6. At load approaching failure of the control beam, samples with confinements were strained approximately less than the control beam between $11.6 \%$ and $38 \%$. 


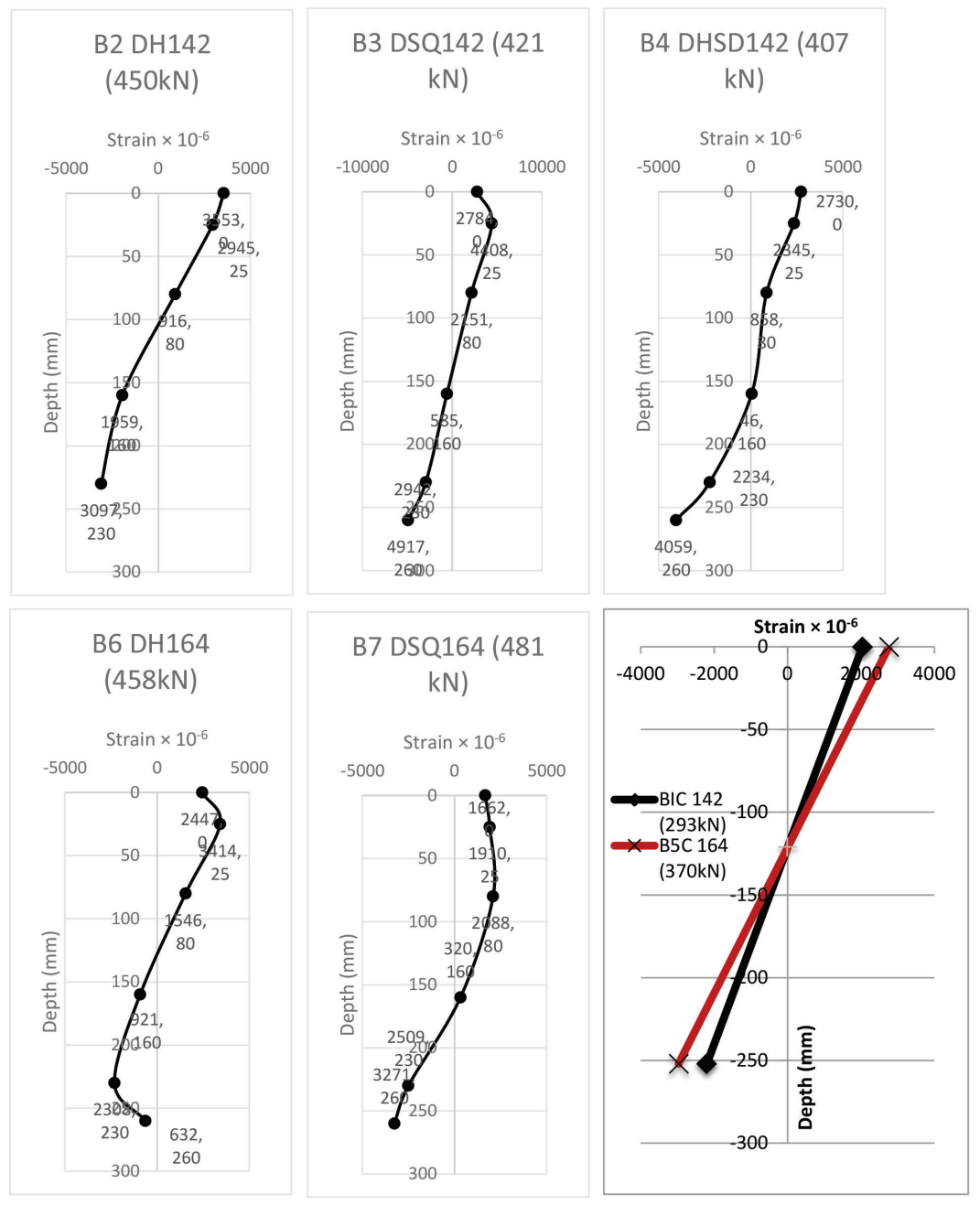

Figure 5: Typical strain profile of beams at failure loads with $\rho=1.424 \rho_{\mathrm{b}}$ and $\rho=1.64 \rho_{\mathrm{b}}$. 


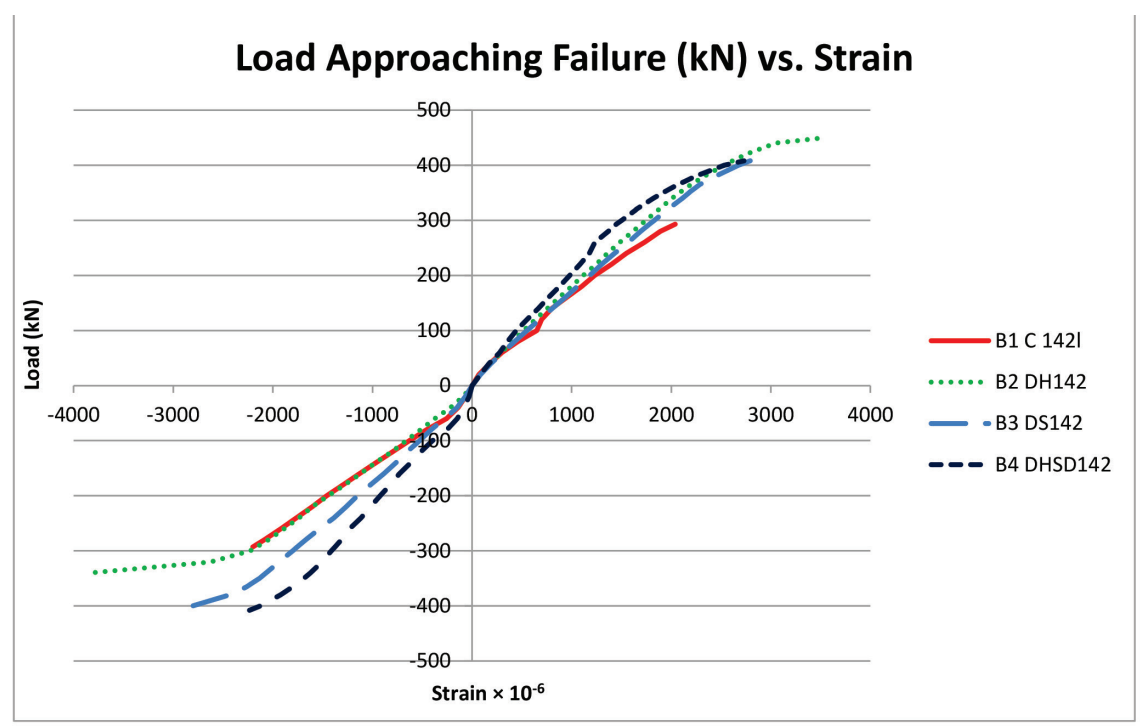

(a)

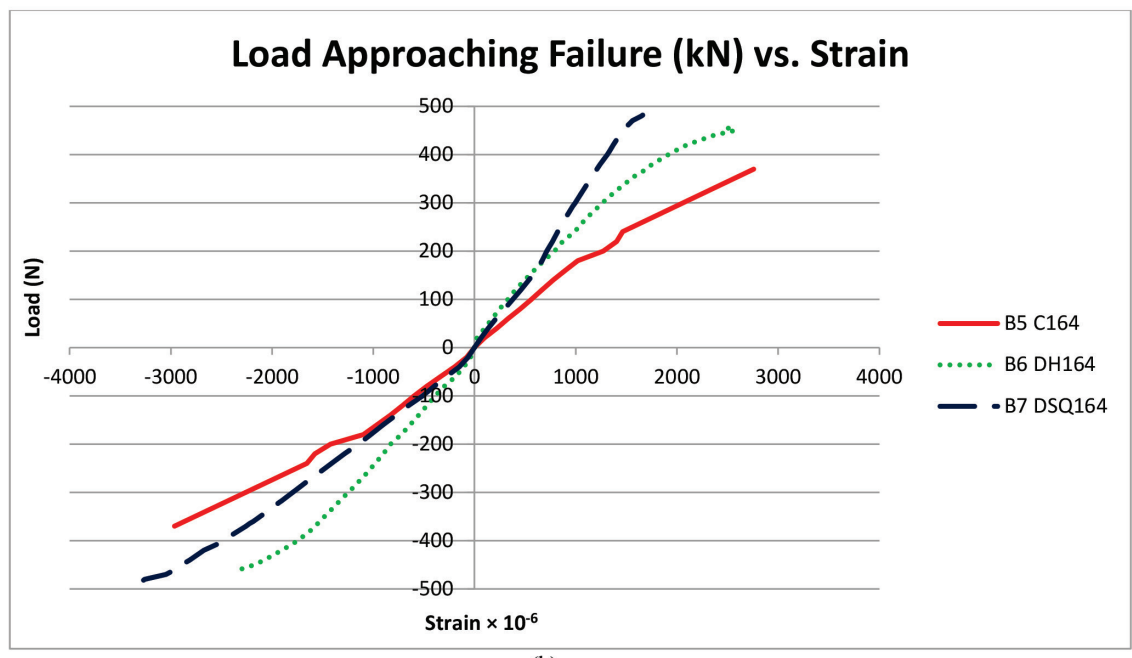

(b)

Figure 6: Illustrations of (a) typical strain profile of beams with $\rho=1.42 \rho_{\mathrm{b}}$, b) typical strain profile of beams with $\rho=1.64 \rho_{b}$.

For beam samples with $\rho=1.64 \rho_{\mathrm{b}}$, at load approaching failure of the control beam, the beam with double helix confinements strained $62 \%$ lesser than the control beam while the beam with the double square confinements strained $228 \%$ lesser than the control beam (more than half that of the control beam). 
Figure 6 also shows the maximum tensile strain at the rebar level. For tensile strain, it was observed that tensile rebars strained lesser than the control beams. With the introduction of concrete confinement, the compressive strength at the compression zone of the concrete had increased, enabling more resistance to compression and also tensile strain.

Table 3: Measured strains at failure load.

\begin{tabular}{llll}
\hline Sample & $\begin{array}{l}\text { Tensile strain in } \\
\text { longitudinal steel }\left(\times 10^{-6}\right)\end{array}$ & $\begin{array}{l}\text { Measured compressive } \\
\text { strain at top of concrete } \\
\text { beam }\left(\times 10^{-6}\right)\end{array}$ & Failure load $(\mathrm{kN})$ \\
\hline B1 C142 & 2200 & 2040 & 293 \\
B2 DH142 & 3097 & 3786 & 450 \\
B3 DSQ142 & 2942 & 2966 & 421 \\
B4 DHSD142 & 2234 & 2977 & 407 \\
B5 C164 & 2970 & 2760 & 370 \\
B6 DH164 & 2308 & 3090 & 458 \\
B7 DSQ164 & 3271 & 1665 & 481 \\
\hline
\end{tabular}

\subsection{Ultimate Load and Ultimate Shear Force}

The calculated ultimate flexural loads and ultimate shear forces based on nominal strengths of materials are compared with the observed failure loads (Table 4). The calculated ultimate flexural loads without partial safety factors for load were carried out in accordance with EC2. It can be seen that the failure loads for all beams were higher than the calculated flexural load. All the samples with confined concrete failed in compression at the maximum compressive zone but not in an explosive manner and have shown reasonable warning against failure.

Due to the confinement effects, the compressive strength at the compressive zone had been enhanced as can be seen in Table 2. Concrete in compression has higher resistance to failure load as reflected by the higher failure of confined concrete cylinders. 
Table 4: Calculated and observed failure load.

\begin{tabular}{|c|c|c|c|c|c|c|}
\hline Beam & $\begin{array}{l}\text { Calculated } \\
\text { ultimate } \\
\text { flexural } \\
\text { load }(\mathrm{kN})\end{array}$ & $\begin{array}{l}\text { Calculated } \\
\text { ultimate } \\
\text { shear load, } \\
\mathrm{V}_{\mathrm{Rd}, \mathrm{s}}(\mathrm{kN})\end{array}$ & Failure type & $\begin{array}{l}\text { Failure } \\
\text { load }(\mathrm{kN})\end{array}$ & $\begin{array}{l}\text { Ratio of } \\
\text { failure } \\
\text { load to } \\
\mathrm{V}_{\mathrm{Rd}, \mathrm{s}}\end{array}$ & $\begin{array}{l}\text { Ratio of } \\
\text { failure load } \\
\text { to ultimate } \\
\text { flexural load }\end{array}$ \\
\hline B1C142 & 292 & 296 & Shear failure & 293 & 0.98 & 1.00 \\
\hline B2DH142 & 289 & 537 & $\begin{array}{l}\text { Gradual } \\
\text { compression } \\
\text { failure }\end{array}$ & 450 & 0.84 & 1.56 \\
\hline B3DSQ142 & 289 & 537 & $\begin{array}{l}\text { Gradual } \\
\text { compression } \\
\text { failure }\end{array}$ & 421 & 0.78 & 1.46 \\
\hline B4DHSD142 & 289 & 537 & $\begin{array}{l}\text { Gradual } \\
\text { compression } \\
\text { failure }\end{array}$ & 408 & 0.76 & 1.41 \\
\hline B5C164 & 327 & 296 & Shear failure & 370 & 1.25 & 1.13 \\
\hline B6DH164 & 323 & 537 & $\begin{array}{l}\text { Gradual } \\
\text { compression } \\
\text { failure }\end{array}$ & 459 & 0.85 & 1.42 \\
\hline B7DSQ164 & 323 & 537 & $\begin{array}{l}\text { Gradual } \\
\text { compression } \\
\text { failure }\end{array}$ & 482 & 0.90 & 1.49 \\
\hline
\end{tabular}

The calculated flexural load of the samples control beams B1C142 and B5C164 are $292 \mathrm{kN}$ and $327 \mathrm{kN}$ respectively. From Table 4, it can be noted that higher failure load was achieved for all beam samples with confinements. The ratio of failure load to ultimate flexural load varies from 1.00 to 1.46 for beams with $\rho=1.42 \rho_{b}$ while for beams with $\rho=1.64 \rho_{b}$, the ratio was approximately 1.45 . The beam with confined concrete gave the highest ratio.

The calculated ultimate shear capacity for the control beams was obtained based on the diagonal compressive strut angle $\theta=22^{\circ}$ and excluding partial safety factors for load. The shear capacity, $\mathrm{V}_{\mathrm{Rd}, \mathrm{S}}$ based on $\theta=22^{\circ}$ is $296 \mathrm{kN}$ for beam B1C142 and beam $\mathrm{B} 5 \mathrm{C} 164$. The shear capacity for the beam samples with confinement were designed to have a capacity of $537 \mathrm{kN}$ with the assumption of $\theta=45^{\circ}$. With the use of over-reinforced concrete beams, the adoption of $\theta=45^{\circ}$ for the design for shear would ensure the beams do not fail in shear.

The design has prevented early shear failure and have utilised the ultimate flexural loads for the beams. The ratio of failure load of confined beams to beams failed in shear ranged between 1.31 and 1.54 . 


\subsection{Deflection}

In terms of deflection, it can be seen that beams with confinements deflected less than the control beams without confinements B1C and B5C as shown in Figure 7 and Figure 8 . For $\rho=1.42 \rho_{\mathrm{b}}$, beams with double helix confinements deflected lesser than the rest while for $\rho=1.42 \rho_{\mathrm{b}}$, beams with double square deflected further less. At the design working load, saving in deflection ranged between $3 \%$ and $14 \%$ for samples with $\rho=1.42 \rho_{\mathrm{b}}$. For samples with $\rho=1.64 \rho_{\mathrm{b}}$, the saving in deflection ranged between $11 \%$ and $25 \%$. The higher the percentage of steel used, the higher the savings in deflection is due to the higher moment of inertia. This agrees well with the lower values of strains obtained.

Figure 9 depicts the cracked beams of the samples except for the control beams as the latter failed in shear. One observation was that all beams had crack lines of $45^{\circ}$ but not failed in shear.

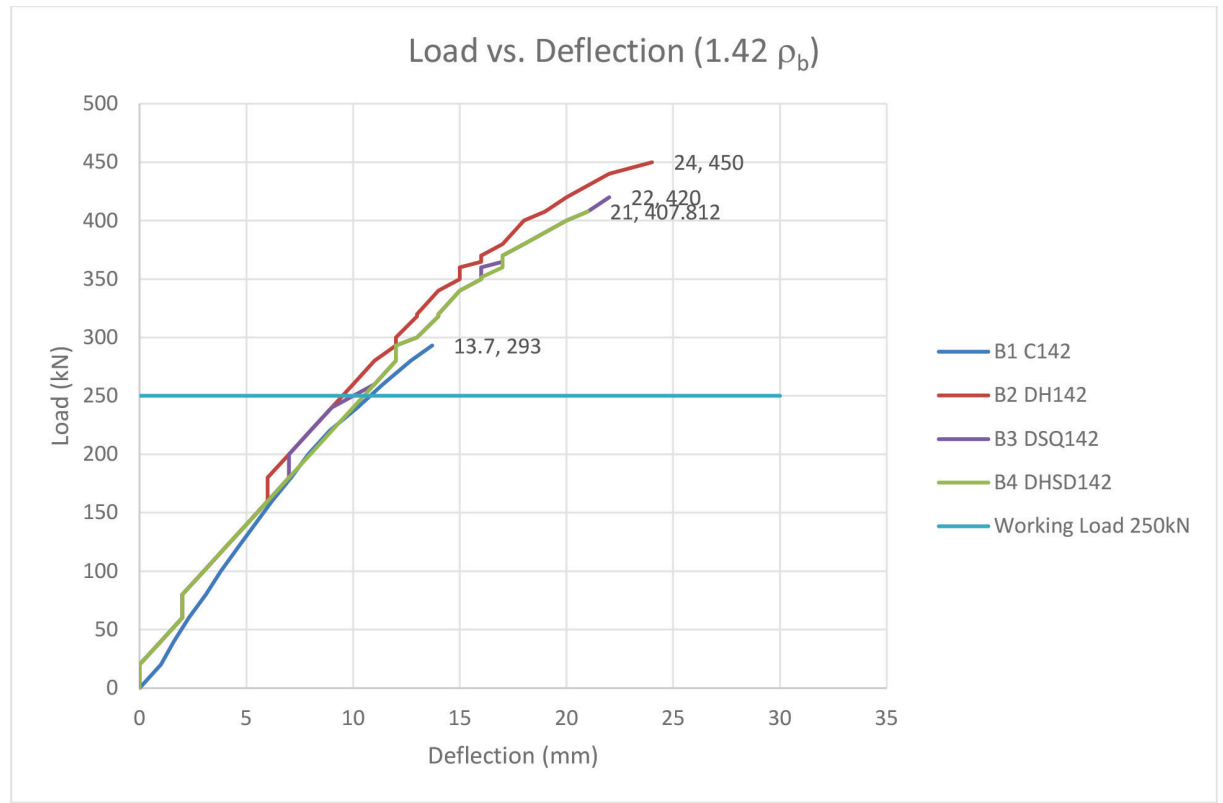

Figure 7: Failure load vs. mid-point deflection B1C 142, B2 DH142, B3 DSQ142 and B4 DHSD 142. 


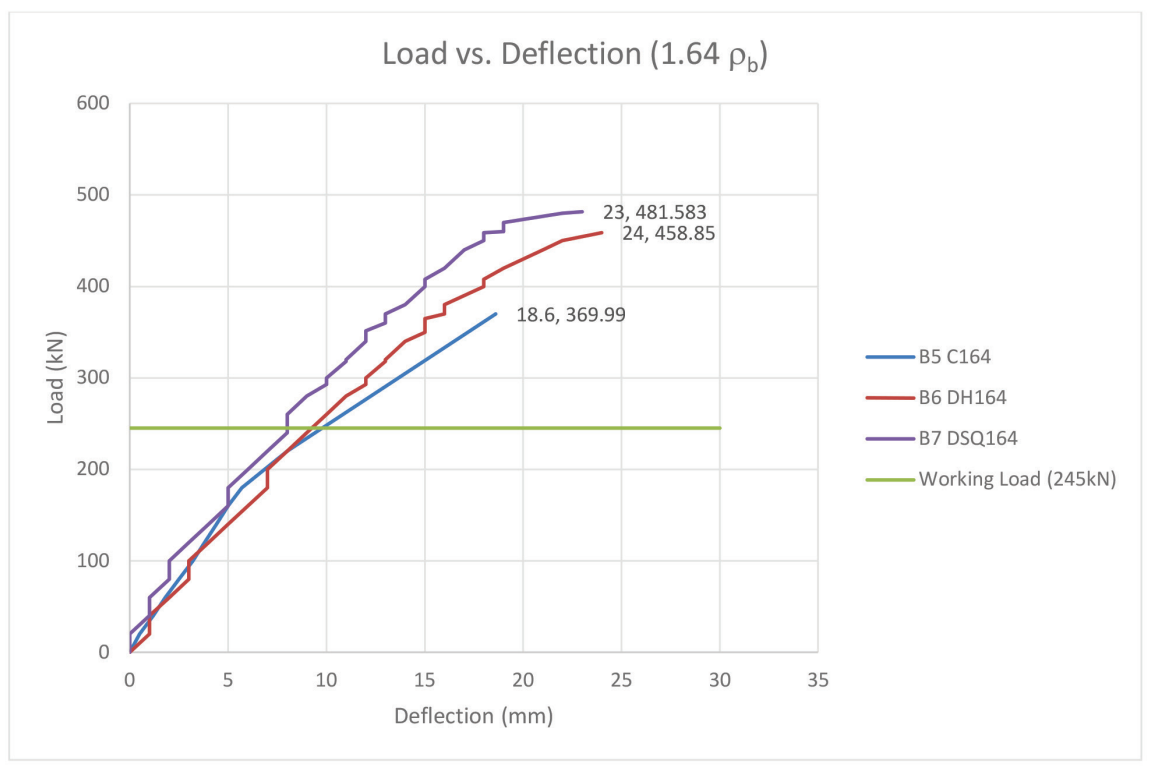

Figure 8: Failure load vs. mid-point deflection for beams B5C 164, B6 DH164 and B7 DSQ164.

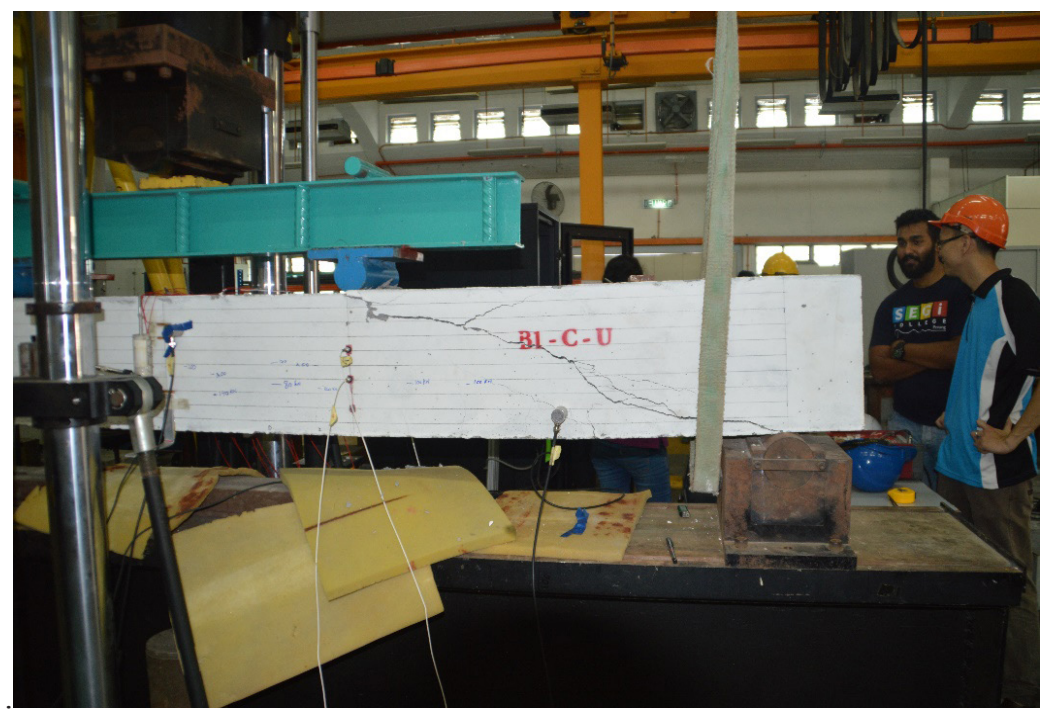

(a)

Figure 9: Illustrations of (a) B1C142 failure load $=293 \mathrm{kN}$, (b) B2 DH142 failure load $=450 \mathrm{kN}$, (c) B3 DSQ142 failure load $=421 \mathrm{kN}$, (d) B4 DHSD142 failure load $=408 \mathrm{kN}$, (e) B5C164 failure load $=370 \mathrm{kN}$, (f) B6 DH164 failure load $=459 \mathrm{kN}$, (g) B7 DSQ164 failure load $=482 \mathrm{kN}$. (continued on next page) 
Figure 9: (continued)

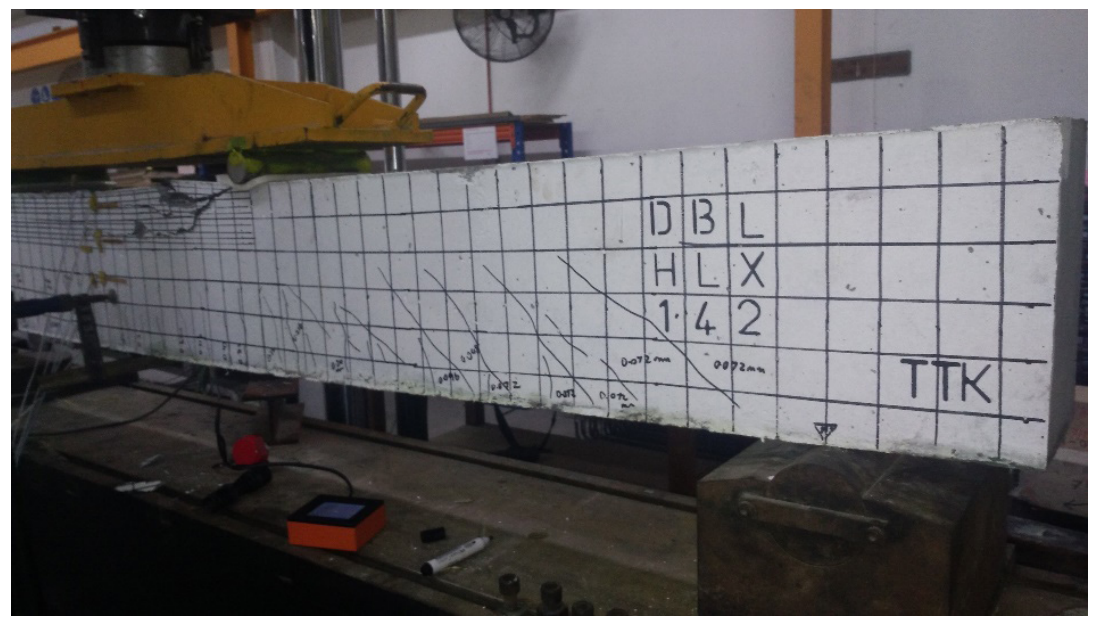

(b)

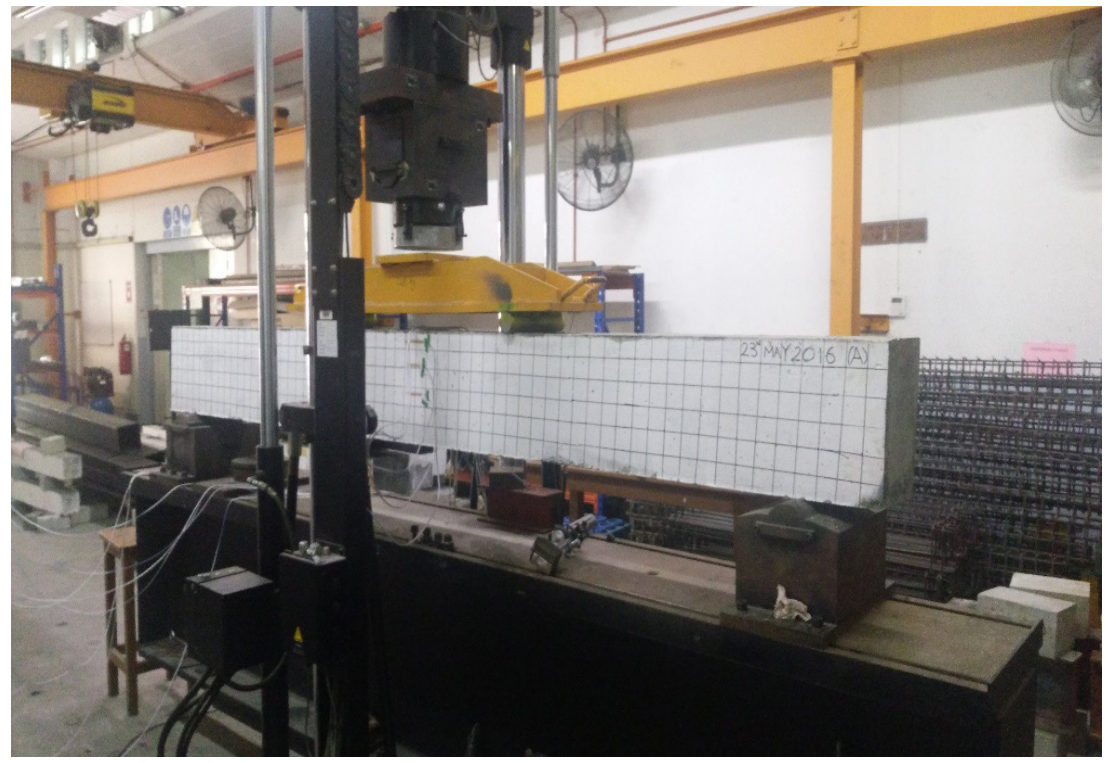

(c)

Figure 9: (continued on next page) 
Figure 9: (continued)

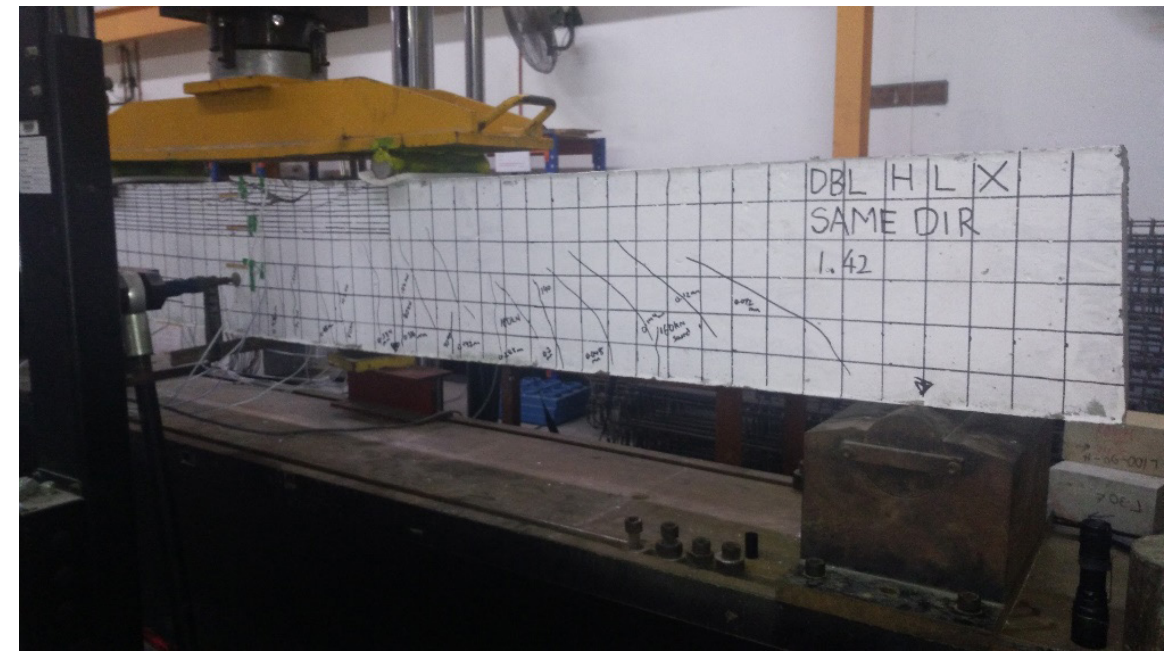

(d)

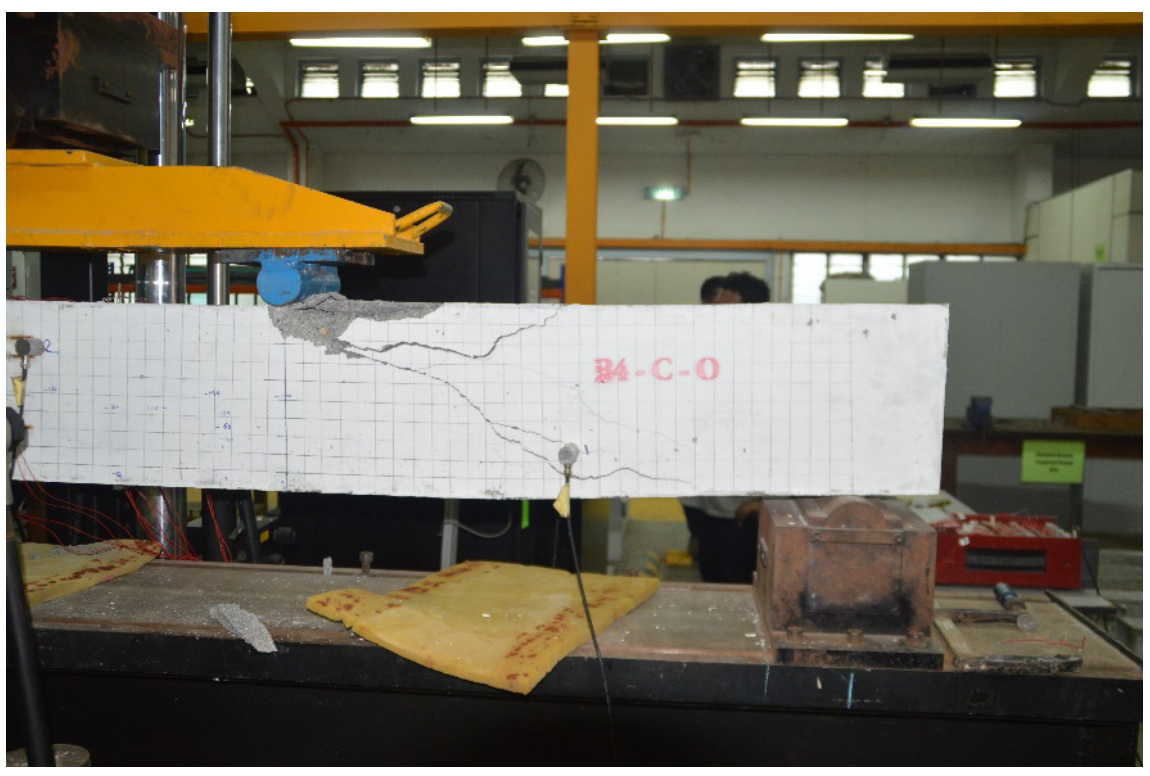

(e)

Figure 9: (continued on next page) 
Figure 9: (continued)

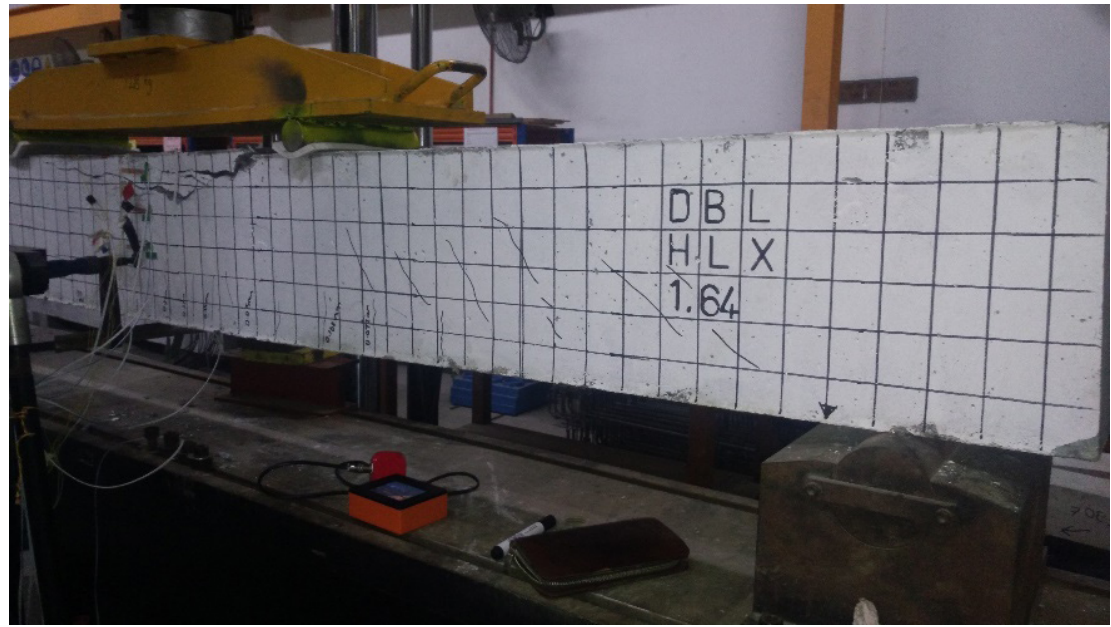

(f)

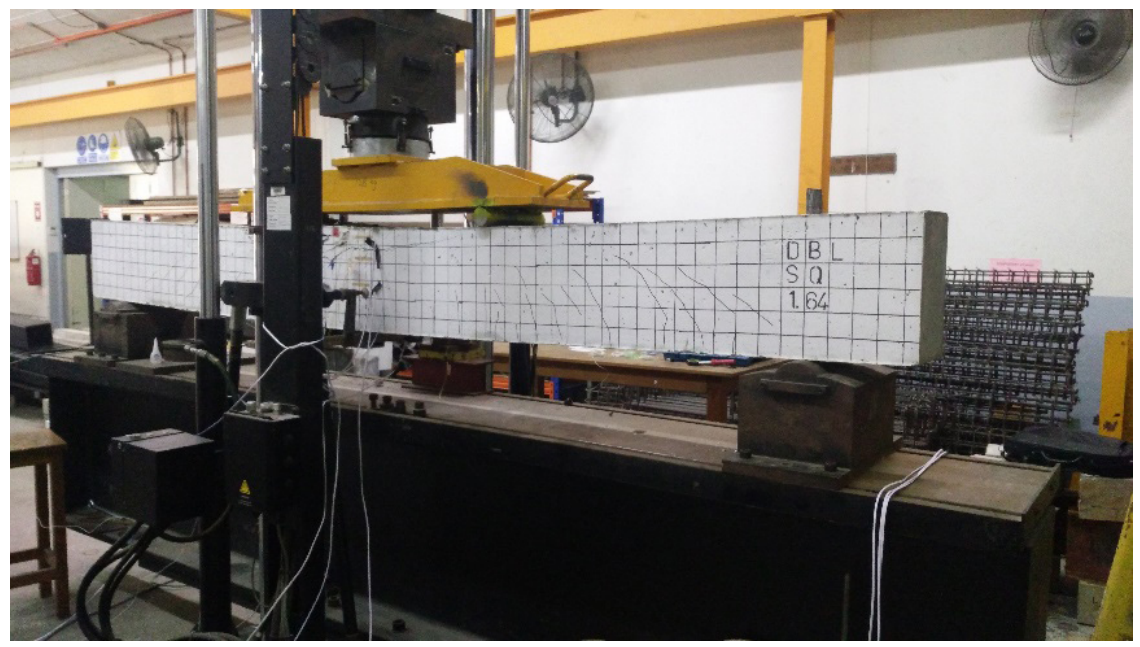

(g) 


\section{CONCLUSION}

Based on the experimental results, it can be concluded that both the tensile and compressive strains for over reinforced concrete beams incorporating confinements will strain lesser compared with the control beams. For reinforced concrete beams incorporating $1.42 \rho_{\mathrm{b}}$ with double helix confinements and at the same level of stress, the tensile and compressive strains were less than beams with double square confinements. On the other hand, for reinforced concrete beams incorporating $1.64 \rho_{\mathrm{b}}$ with double square confinements, the compressive strains were less than beams with double helix confinements which indicated that for higher steel ratio, the double helix confinement has limited effect on reducing the strain values. The flexural strength of all beams with confinements exceeded the calculated ultimate flexural loads. The beams with confinements must be designed using the diagonal compressive strut angle $(\theta)$ of more than $22^{\circ}$ and this ensured that shear failure did not occur. The deflection of the beams with confinements deflected less than the control beams at the same level of stress.

\section{ACKNOWLEDGEMENTS}

The authors would like to thank SEGi University, Malaysia for the internal grant, with reference number SEGiLRF/2014-34/FOEBE-11/49 and also Chen Ming Wong, former student of SEGi University for his assistance in preparation of the strain gauges. The authors also thank the technicians at Universiti Malaya, Malaysia where the experiment was conducted.

\section{REFERENCES}

1. Cusack, P. (1981). Reinforced concrete in Britain: 1897-1908. PhD diss, University of Edinburgh, Scotland.

2. Considere, A. (1908). Experimental researches on reinforced concrete. New York: McGraw Publishing Company.

3. Carreira, D. J. \& Chu, K. H. (1985). Stress-strain relationship for plain concrete in compressio. ACI J., 82, 797-804

4. Mander, J., Priestley, M. \& Park, R. (1988). Theorectical stress-strain model for confined concrete. J. Struct. Eng., 114, 1804-1826.

5. Mangat, P. S. \& Motamedi Azari, M. (1985). Influence of steel fibre and stirrup reinforcement on the properties of concrete in compression members. Int. J. Cem. Compos. Light Concr., 7(3), 183-92 
6. Němeček, J., Padevět, P. \& Bittnar, Z. (2004). Effect of stirrups on behaviour of normal and high strength concrete columns. Acta Polytech., 44(5), 158164.

7. Marvel, L. et al. (2014). Axial behavior of high-strength concrete confined with multiple spirals. Eng. Struct., 60, 68-80.

8. Ziara, M. M., Haldane, Ã. D. \& Hood, S. (2000). Proposed changes to flexural design in BS 8110 to allow over-reinforced sections to fail in a ductile manner. Mag. Concr. Res., 52(6), 443-454.

9. Mosley, B., Bungey, J. \& Hulse, R. (2007). Reinforced concrete design to Eurocode 2. New York: Palgrave Macmillan.

10. Kong, F. K. \& Evans, R. H. (1993). Reinforced and prestressed concrete. London: Chapman \& Hall.

11. Ahmed, M. M. et al. (2007). Effect of confining method on the ductility of over-reinforced concrete beams. J. Eng. Sci. Assiut Uni., 35(3), 617-633.

12. Jang, I-Y. et al. (2009). Flexural behavior of high-strength concrete beams confined with stirrups in pure bending zone. Int. J. Concr. Struct. Mater., 3(1), 39-45.

13. Priastiwi, Y. A. et al. (2014). Behavior of ductile beam with addition confinement in compression zone. Proced. Eng., 95, 132-138.

14. Priastiwi, Y. A., Imran, I. \& Nuroji. (2015). The effect of different shapes of confinement in compression zone on beam's ductility subjected to monotonic loading. Proced. Eng., 125, 918-924.

15. Ali, A. M. \& Tarkhan, M. A. (2015). Experimental investigation of confining the compression zone in over-reinforced beams. Int. J. Eng. Sci. Res. Tech., 4(11), 611-617.

16. Jeffry, R. \& Hadi, M. N. S. (2008). The effect of confinement shapes on over-reinforced hsc beams. World Acad. Sci. Eng. Technol., 2, 260-267.

17. Kuttab, A. S. \& Haldane, D. (1991). Detailing for shear with the compressive force path concept. IABSE reports, 62, 661-666.

18. Elbasha, N. \& Hadi, M. N. S. (2005). Effect of helical pitch and tensile reinforcement ratio on the concrete cover spalling off load and ductility of HSC beams. Proc. Austr. Struct. Eng. Conf., 54-64.

19. Hadi, M. N. S. \& Elbasha, N. (2008). The effect of helical pitch on the behaviour of helically confined HSC beams. Constr. Build. Mater., 22, 771780 .

20. Hadi, M. N. S. \& Elbasha, N. (2007). Effects of tensile reinforcement ratio and compressive strength on the behaviour of over-reinforced helically confined HSC beams. Constr. Build. Mater., 21, 269-276. 
21. Tee, H. H., Al-Sanjery, K. \& Chiang, J. C. L. (2016). Behaviour of reinforced concrete beams with confined concrete related to ultimate bending and shear strength. Paper presented at the AIP Conference Proceedings, Semarang, Indonesia, 5 Oct.

22. British Standards Institution (BSI). (2007). Eurocode 2: Design of concrete structures, part 1-1: General rules and rules for buildings. London: BSI. 